\title{
To the Cheshire Station: Alan Garner and John Mackenzie's Red Shift (1978)
}

Brian Baker

In Alan Garner's 1973 novel Red Shift, set within the county of Cheshire, one of the interconnected male protagonists, Tom, stands upon the hill of Mow Cop, a site which is important to the three layered narratives (in Roman Britain, at the time of the Civil War, and in the present) that make up the novel. Negotiating an increasingly difficult (and long-distance) relationship with the trainee nurse Jan, Tom begins to psychologically disintegrate under pressure from his family and in trying to manage his own feelings. On Mow Cop, he asks Jan 'Where am I?', and then provides his own answer:

'My right leg,' said Tom,' at this moment, is in the township of Odd Rode, in the parish of Astbury, in the hundred of Northwich, and the county and diocese of Chester, in the province of York. My left leg is in the township of Stadmorslow, in the parish of Wolstanton, in the hundred of Pinehill, in the county of Stafford, in the diocese of Lichfield, in the province of Canterbury. You see my predicament. [...] [I]t's worse in there. There, the map says, the boundary is undefined.' (Garner 2002: 110)

An emblem of Tom's own psychological dislocation and lack of definition, Mow Cop, which stands on the border of Cheshire and Staffordshire and between the Midlands and the North, is a literal projection of an emotional and psychological state. As I will undertake to analyse in this chapter, both Garner's Red Shift and the BBC Play for Today adaptation of the novel, which was broadcast in 1978, are filled with images of physical mobility and of communications technologies: the M6 motorway, Crewe railway station, bicycles, a cassette recorder, written letters (the novel ends with one, given to the reader in code). In Red Shift, Garner's locatedness in the particular landscapes, topography and places of 
Cheshire - in fact East Cheshire, from Alderley Edge out towards Garner's birthplace near Congleton - is in tension with a recurrent motif of transmission, of words and people and vehicles moving through the county. The M6 motorway connects up the urban and industrial centres of the West Midlands with the commercial and logistical networks of the North West; Crewe railway junction is a hub that connects London, Liverpool and Glasgow on what is known as the West Coast Mainline, along with numerous interchange lines to Manchester, Chester and Holyhead, and the Potteries. Cheshire is characterised, in Red Shift, by being in transit, in flux rather than fixed in space (and, in the novel's narrative structure, in time). As Tom says about Mow Cop, its boundaries become 'undefined'.

In a sense, this is unusual in Garner's oeuvre, for his work is known for its long negotiation with the country of Cheshire, its rootedness in Cheshire's villages and hills, its myths and histories. Garner's first novel, The Weirdstone of Brisingamen (1960), is a fantasy novel in which two children discover a miraculous cave under Alderley Edge, in which the forces of light lay dormant and await the necessity of awakening to battle the forces of darkness, and its sequel, The Moon of Gomrath (1963), traverses the same geography. Later novels such as Boneland (2012), which completes the Weirdstone sequence, and Thursbitch (2003) are also deeply invested with actual places in Cheshire. (Walks are conducted around the Thursbitch topography for interested readers.) Cheshire seems to be a fixed place in Garner's imagination, one in which historical and mythic resonances can be transmitted through place and across time. However, this is to somewhat misconstrue the actual geography and history of the county. If Cheshire is understood to be defined by its borders, then 
these have changed over time. Some are fixed by geography: the northern edge of the county is defined by the path of the River Mersey - the other bank is Lancashire - and rather more porously, the conurbation of Greater Manchester. To the south-west, it is defined by the path of the River Dee and the Welsh hills (where I write this chapter). To the East, the Pennines. In a history of the county, Alan Crosby writes that, standing upon Shining Tor above Macclesfield, it is possible to see all of 'historic Cheshire [...] in that single view. It thus has a very clear geographical unity and coherence' (Crosby 1996: 13). And yet some of its borders and boundaries have changed markedly. A map of historic Cheshire looks something like the tilted head of a bull, with two horns sticking out: the Wirral peninsula to the north-west, and the narrow Longdendale isthmus to Mottram and Tintwistle in the north-east. Local government reorganisations have shorn these two horns: Longdendale is now part of Greater Manchester (Tameside), while the Wirral is a separate authority. Cheshire's bull (a creature that is central to the narrative of Thursbitch) has been mutilated, its geography and boundaries altered.

It is also worth considering that Cheshire is a boundary: between England and Wales to the west, and between the North of England and the Midlands to the South. Paul Morley, in The North (and almost everything in it) (2014) writes:

Few English counties owe more of their history to their geographical position and surroundings, and to the character of their natural features, than Cheshire.

The north begins in the Cheshire Plain, a flat area of land covering thousands of square miles bounded by the hills of north Wales to the west, the Derbyshire Peak District to the east and the Pennines to the north-east. It was once under the ocean, but emerged from the water, dried out, leaving vast salt deposits, and remained remote from the early maritime influences affecting the English South. It begins with the mossy, 
peaty, fast-flowing or lazily drifting rivers cutting through the plain. (Morley 2014: 8).

In Morley's short locating of the North 'beginning' at the Cheshire Plain, we find fixity (the ranges of hills on the borders) and flux (the rivers), the importance of nature and natural resources, the crucial role of movement across the terrain (the rivers and the salt-routes that are important to Garner's Thursbitch), and also isolation, remoteness, dislocation.

In many of Garner's texts, there is a direct connection between land and sky. In Red Shift, Tom and Jan try to ensure some kind of emotional closeness by looking up at the constellation of Orion at the same time on a winter's night, their consciousness of each other transmitted through the astrological sphere. Unlike the rather more mystical and trans-historical connection between Tom, Macey and Thomas Fowler, the three male protagonists of the novel, this purely visual nexus quickly degrades. In 'The Edge of the Ceiling', an autobiographical essay in Alan Garner's non-fiction collection The Voice That Thunders (1997), Garner talks about his childhood in Cheshire when, sequentially confined to his room by diphtheria, meningitis and pneumonia, he discovered 'a forest in the ceiling, with hills and clouds, and a road to the horizon' (Garner 1997b: 10). Between sleeping, catnapping and coma, Garner suggests that he was able, by 'switching himself off', to enter a different world in the ceiling, to 'live' in the ceiling when his ability to 'live' in the 'real' world of Cheshire was reduced by chronic pain and debility. Reduction pertains more to the world of the ceiling than to Garner's bedroom, however. While 'the world of the ceiling was three-dimensional, objects were solid, visual perspectives true' (Garner 1997b: 11), Garner writes 
that the world of the bed became 'the permanent choice' of where to truly live because of the constraints of the world of the ceiling:

Although the way to the ceiling was along the same road in the ceiling, the land beyond the road, from visit to visit, was inconsistent; and this inconsistency made the ceiling not more interesting but less. Each venture was separate rather than a learning, and such variety leads nowhere; it builds nothing; it has nothing to teach. And I wanted to learn. That was the difference. I would enter the ceiling by an act of will, but left it through tedium. Sooner or later, I would stop whatever I was doing in the ceiling, turn around, and always be facing the same road-forest-cloudhill picture that I saw from my bed. Then I would pull back as a camera does to the bed and lie looking at the lime-wash plaster. (Garner 1997b: 11-12)

Without wishing to assert some kind of biographical 'key' to Garner's writing, this relation between the bed and the ceiling seems to figure the spatial and temporal relationships in many of Garner's books. There are two spatial planes, and an observer or observers whose consciousness forms a kind of bridge or conduit between these planes (or, as in Red Shift, between each other). The ceiling can be taken to figure the relation between land and sky, but it also represents a spatio-temporal relation between different historical periods which come into contact through some kind of emotional, psychological or ritual resonance. Garner's texts are planar fictions. They are structured with two (or in Red Shift, multiple) planes that move independently in time/space but can be brought into alignment through the workings of an object (the 'thunderstone' or axe-head) or through consciousness (the bed and the ceiling, the visions that connect Macey, John Fowler and Tom in Red Shift). They are not fictions of mapping but rather fictions of the alignment of co-ordinates: it is no coincidence that 'The Edge of the Ceiling' begins 'My name is Alan Garner, and I was born, with the cord twice wrapped round my throat, in the front room of 47 Crescent 
Road, Congleton, Cheshire, at Latitude $53^{\circ} 09^{\prime} 40^{\prime \prime} \mathrm{N}$, Longitude $02^{\circ} 13^{\prime} 7^{\prime \prime} \mathrm{W}$, at

21.30 on Wednesday, 17 October 1934' (Garner 1997b: 3). There is not a direct connection between stars and markers on the land in terms of an astrocartography, but instead a ritual relation that has to do with movement and conjunction.

These conjunctions allow connection across time. In his essay 'Inner Time', collected in The Voice That Thunders, Garner explores the centrality of space, boundary and flow to narrative and to myth. The 'flow of myth' is, according to Garner, 'the most important function of literature, the one to which we turn in our greatest stress':

Man is an animal that tests boundaries. He is a 'mearcstapa', 'boundarystrider', and the nature of myth is to help him to understand the boundaries, to cross them and to comprehend the new; so that, whenever Man reaches out, it is myth that supports him with a truth that is constant, although names and shapes may change. From within us, from our past, we find the future answered and the boundary met. It may well be asked why we hold the key to questions we do not yet know, from what space and what time the myth flows. (Garner 1997a: 108)

We can see here how strong the connection are to Red Shift, and in fact 'Inner Time' was first given as a lecture to the ICA in London in 1975, two years after the novel's publication. Tom, in the scene we began with, 'tests the boundaries', and so does the novel: the boundaries of historical time, the boundaries of the space of Cheshire, the boundaries of the individual human consciousness. In the essay, Garner describes a personal moment of psychological breakdown that happened to him while he was involved in the 1969 Granada Television adaptation of his novel The Owl Service (1967), in terms that reflect this motif of conjunctions across time: 
When I set out to assault the actor during the filming of The Owl Service, it was because I could not reconcile him and me on a Welsh mountain in 1969 with the memory-trace of me somewhere else in 1950. The inner time co-ordinates were identical but they had been externalised to a hereand-now of waking nightmare. Inner time rules of simultaneity and onedimensionalism had been projected on a four-dimensional space-time. Which was absurd. Or I was. (Garner 1997a: 115)

This personal and painful mapping of co-ordinates, of different historical planes, requires a form of psychological treatment which (perhaps unsurprisingly) takes on the form of ritual or something mystical: the painful conjunction is undone by a psychotherapist who asks one question, which 'unlocks' the seized conjunction and allows Garner to recover his equilibrium. This is akin to a magical phrase or even code-word; as we will see with ending of Red Shift, codes are particularly important to reading the narrative. The question the psychotherapist asks is: 'Was The Owl Service written in the past tense and the third person or the present and the first?' (Garner 1997a: 112). Wittily, the question asks whether Garner can tell the difference between past and present, narrative and 'real', himself and the world.

The relation of Garner's novels to the adapted screen text is put into question in 'Inner Time', therefore. For the author, the conjunction between inner and outer, between text and world, dissolves in a moment of agonising (and near-psychotic) breakdown. Re-establishing that 'undefined boundary' is thereby the path back to psychic health. The Owl Service was filmed in Wales (where the novel is set) in a prestige children's series, written by Garner himself and produced and directed by Peter Plummer. It has since attained the status as a 'classic' adaptation for its production values and proximity to Garner's text. A later Children's BBC adaptation of Elidor (1965), a novel in which children slip 
from Manchester slums into a fantasy realm through a kind of portal, was produced in 1995 with Garner's involvement, but with lower production values and being shot on video rather than film, this 6-part series is much less effective than The Owl Service and certainly lacks its status. Between the two was Red Shift, adapted by Garner into a 90-minute television play (rather than series), broadcast in the evening/ adult audience Play for Today slot on 17 January 1978, and directed by John Mackenzie, who had worked as an assistant to Ken Loach on Up The Junction (1965) and Cathy Come Home (1966), very well-known social realist dramas, and who would later go on to a film career that included the British gangster film The Long Good Friday (1979).

The film of Red Shift begins at night, with out-of-focus headlights of cars on a motorway, with Phil Ryan's musical score a combination of a pulsing and streamlined rock beat (reminiscent of the 'Krautrock' band Neu! and the 'Dingerbeat' named after the band's drummer) with synthesizer pads and musical phrases strongly reminiscent of the BBC Radiophonic Workshop. These headlights fade into stars and a rotating galaxy in centre screen, indicating science-fictional generic markers; and in a further recognisable reference to BBC science fiction television, the three main actors playing the characters of presentday Tom (Stephen Petcher), Civil War-era Thomas Rowley (Charles Bolton) and Roman soldier Macey (Andrew Byatt) are superimposed upon the stars and galaxy in a technique familiar from the title sequence of the period's Doctor Who. About the novel Red Shift Alan Garner wrote 'I use the phrase [science fiction] with reticence. "Science fiction" has the sound of a botched-up job, but what it describes is [...] the flow of myth' (Garner 1997a: 108). Is the novel, or the 
television film of Red Shift science fiction, then? The generic markers and title sequence of the play certainly seem to suggest so, although its handling by Mackenzie remains within the codes of televisual realism: there is one bluefiltered, slow-motion shot later in the film, denoting one of Macey's visions, but otherwise the filming is remarkably free from any kind of special effect, although the synthesized score also seems to suggest sf as genre. As Neil Philip suggests in his monograph on Garner, A Fine Anger (1981), Red Shift 'is a novel about time' in which time 'is perceived not as a continuum but as continuously present, and the three stories develop, both independently and interdependently, with no sense of one being contemporary and the others "history"' (Philip 1981: 86, 87), and this remains true of the screen adaptation. However, in terms of linear sequence, the 'present day' narrative, considering the tortured and increasingly long distance (spatially and emotionally) romance between Tom and Jan (Lesley Dunlop), comes first in the tv play, suggesting its priority.

After shots from the windscreen of a car travelling down the motorway, there are three shots of the two actors walking by the side of the motorway, in rapid sequence, from cars passing in both directions. This cutting emphasises the tripartite narrative structure of the play, and replicates (and in fact supplants) Garner's textual working of the 'thrice-told' moment in a later scene where Thomas Rowley, his fiancé Marge (Myra Frances) and another Thomas, Thomas Fowler (a figure from Civil War history, played here by James Hazeldine) confront each other; in the novel, this scene is presented three times, in slightly different ways, from each of the points-of-view of the three characters. The television play avoids such techniques, and presents this scene once; but its editing increasingly avoids strongly marked transitions between historical 
periods and narratives: there are no dissolves or other visual effects used. Only the first transition, between Tom shattering the window of his parents' static caravan in the present and a sword slashing rents in the fabric of Macey's tent in Roman times, offers anything like a match on action or some kind of visual bridge to allow the viewer to orient between the two narratives. Indeed, as the play progresses, the markers of transition between times are removed, and even the markers of transition between spaces are elided: instead of showing Tom and Jan riding out to Mow Cop, the 'blue-silver' livery of the then British Rail trains flashing past the stationary camera at Crewe railway station provides the most fleeting of punctuation marks.

The emphasis on 'blue-silver' corresponds most importantly with Macey's narrative. As a youth, Macey witnessed the slaughter of his village, which provoked him into a 'berserker' state in which he killed 11 soldiers; taken in by his Roman squad-leader Logan (Ken Hutchison), Macey becomes a kind of weapon himself, wound up into homicidal fugues by Logan when the squad is in danger. This is presented to the viewer in the first section of the Roman narrative: attacked by the local tribespeople, Macey seizes a stone axe-head (even at the time a votive and ancient object) and clubs several of his enemies to death, covering the axe-head and his hands with blood. As I noted above, Garner's fictions often use spatial or topographic zones as portals between historical periods or worlds (the Fundindelve caves in The Weirdstone of Brisingamen, or the valley in Thursbitch) but here it is the stone axe-head that connects the three periods, as well as the unusual psychic sensibilities of its three male protagonists. Macey, we see at the end of the play (in a scene added to the novel's narrative) buries the stone axe, perhaps as a blood-price for his life- 
taking; it is found by Thomas Rowley in 1643, just prior to the invasion of the village by Royalist irregulars; and Tom and Jan find the axe-head cemented in to the chimney of a ruined cottage on Mow Cop, presumably put there by Thomas Rowley (or his wife Margery). The axe-head is then an object transmitted across the narrative time-frames, remaining rooted in the deep history of place until Tom (in his greatest betrayal of Jan) sells the object to a local museum.

There is, I would suggest, another tripartite structure at work in Red Shift with regard to the interconnection of historical time-periods. Firstly there is the axe-head, a trans-temporal object; secondly, there are the connected sensibilities of Tom, Thomas Rowley and Macey; and thirdly, there is the persistence of place or space, the sites upon which the narrative takes place. The first is Rudheath, by the M6, where Jan and Tom live; the second is Mow Cop, doubled with Barthomley Church; and the third is Crewe railway station. While the first and third spaces are themselves characterised by mobility and transport infrastructures, the double space of Mow Cop/ Barthomley is marked as a place of refuge, even though the sanctuary is violated by the assault on the church by the Royalist soldiers. While Rudheath and Crewe station are spaces of flux and transition, Mow Cop and Barthomley are places of fixity - paradoxically in Mow Cop's case, as we saw at the beginning of this chapter, where Tom talks about the hill in terms of the 'undefined boundary'. While the film shoots Tom and Jan, and the Roman characters, in different parts of Mow Cop (the ruined cottage that is central to the present-day narrative would not, of course, have been there in Roman times), there is a clear topographical contiguity between the two sequences: although they are presented as taking place at different times, they are in the same physical space. This is not to say that the way the two narrative 
sequences present the space of Mow Cop is absolutely identical: the shots are much more narrowly delimited in the Roman narrative to mask any destabilising signs of subsequent occupation and use. As I noted above, however, the consistent use of a realist mode of narrative presentation, and the increasing elision of any markers of temporal transition between one time (and space) and another in the editing, tend to produce the sense that these narratives are spatially overlaid, a kind of palimpsest.

The crucial connective thread, the centre around which the narrative universe of both novel and television play rotate, are the connected sensibilities of its three male protagonists. Tom, in the present day, seems to be the youngest; studying for A-levels (the novel obliquely suggests), he is a rather troubled young man, intellectual but emotionally blocked, finding in the words of others the means by which to communicate with others or occasionally, to ward them off. This recourse to verbatim quotation - 'Tom's a-cold' is a key phrase in the novel which is not taken up in the adapted text, but there are many others seems to suggest some kind of inauthenticity with regard to communication, the incapacity of words to really transmit what Tom feels. In the novel, it is little wonder that he and Jan have recourse to a code when writing letters to each other, to bypass his mother's surveillance; his communications are alwaysalready coded. His upbringing, to an Army Sergeant-Major and his wife, a rather controlling and infantilising mother who views Jan as a rival and harbours a somewhat hysterically-presented attitude towards teenage sexuality, is portrayed as being deformed by spatial proximity: his 'bedroom', a curtained alcove by the caravan's kitchen, affords no privacy. Indeed, both novel and play show Tom putting on his 'cans' (headphones) to listen to music to block out the 
too-present world around him. For Tom, blockage of hearing, of language and of vision marks him not only as the latest incarnation of a masculine visionary subjectivity, but also perhaps as the least.

The most intellectualised - the others possess little knowledge and no learning, although Thomas Rowley is interested in learning to read and write Tom does not have the visionary fugues or fits that possess the two other young men. Towards the beginning of the play, as Tom and Jan stand outside her parents' house, a motorbike is heard passing by (in a kind of Doppler effect - and important motif I will return to), but added to this is the sound of a male scream. Tom reacts to this, but Jan does not. The film here plays with the diegetic status of this sound: is it external or internal? Can the viewers and Tom hear it, but Jan cannot? Afterwards he sits, curled into a ball, and talks of things becoming inverted or wrong-way around, clearly disturbed. The source of this disturbance - emotional, psychic or 'supernatural'/ trans-temporal - is never located. Unlike Thomas Rowley, who we see having what appears to be an epileptic seizure on the roof of Barthomley church, or Macey, whose 'blue-silver' vision is the only filtered shot in the play's fabric, Tom's ability to connect across time, just like his ability to connect to others emotionally and through language, seems fatally blocked.

Thomas Rowley is, by comparison, much more intellectually limited than Tom, and in his seizures much more physically debilitated by his visions, but he seems less troubled by them. He puzzles over what they might mean, but it is Thomas Fowler, the leader of the Parliamentarian faction at Barthomley and who harboured an unrequited love for Margery (or in the tv play, Madge) Rowley who 
seeks their spiritual meaning. In a scene with Margery in the novel, substantially presented in the play, Fowler says:

'He already knows more than I could learn.'

'And you don't bait me. You and your reading and that.'

'It's what we make do with, if we can't be Thomas Rowley.'

'But - books, Latin -'

'The greater part of rubbish.'

'But when he's badly -'

' - that man sees God.' (Garner 2002: 53)

Fowler asks Rowley directly whether he sees God or not, but Rowley can find no answer. The proximity of the two surnames and their shared first name clearly marks these two male figures as doubles; but in this narrative there is a third, Thomas Venables, a former inhabitant of the village who is now a part of the Royalist forces, a man of violence who helps sack the church, rapes Margery and stabs Rowley, but then goes on to help them both escape. In the Roman narrative, the male visionary is surrounded by his 'brilliant mates', the squad of Roman soldiers who form a homosocial support group that ultimately fails to keep them alive; in the Civil War section, the visionary male seems to be split into three separate Thomases; and in Tom, this is reduced to an isolated and blocked young man who struggles to keep any kind of emotional or linguistic connection to others.

The Civil War narrative is based on a historical incident that took place in Barthomley on 26 December 1643. As Neil Philip notes, the massacre that took place there is 'well documented', and he quotes from the account of Thomas Malbon, a contemporary attorney from Cheshire who wrote the following account:

The Kinges ptie. comynge to Barthomly Churche, did sett upon the same; wherein about XX Neighbours where gonne for their saufgarde. But maior 
Connaught, maior to Colonel Sneyde, (whome they in the Churche did take for the Lord Brereton,) with his forces by wyelcome entred the Churche. The people within gatt up into the Steeple; But the Enymy burnynge formes, pewes, Rushes \& the lyke, did smother theim in the Steeple that they were Enforced to call for quarter, \& yelde themselves; which was graunted them by the said Connaught; But when hee had theim in his power, hee caused theim to all to be stripped starke Naked; And most barborouslie \& contr'y to the Lawes of Armes, urthered, stabbed and Cutt the Throast of xij of theim; viz: m'John ffowler (Scholem'), Henry ffowler, $m^{\prime}$ Thomas Elcocke [...] \& wounded all the rest, leaving many of theim for Dead. (Philip 1981: 95)

Garner uses many of the names given in this account, and follows Malbon's narrative almost entirely, though adding that John Fowler is the son of the Rector who eventually (in the mistaken hope of saving the others) betrays his son to the Royalist troops. Garner somewhat downplays the political aspect of this massacre: that John Fowler was a Parliamentarian, whose arrest and execution by Royalist soldiers is part of a much wider conflict in Cheshire between the two forces. The city of Chester, in the far west of the county, was a Royalist stronghold, and was in fact besieged by Parliamentarian forces during the Civil War, and was one of the last Royalist strongholds to fall in February 1646; but although support of the gentry in the county was split between Royalist and Parliamentarian, the major towns in the middle and west of the county Stockport, Northwich, Knutsford, Congleton - were Parliamentarian garrisons (Crosby 1996: 60). That the county was split, that this was a 'Civil War', is downplayed in Garner's Red Shift, where the Royalist forces are recurrently characterised as 'Irish': they are invaders, from without. Thomas Venables (based upon another historical figure) is almost a Judas-figure, a betrayer from within the community, but as I noted above, his ambiguous actions (raping Margery but saving both her and Thomas Rowley from death) complicate the 
conflict. This sense of 'invaders' is itself somewhat underplayed by Mackenzie in the television adaptation of Red Shift. The commander of the Royalist troops speaks with a similar Northern English accent to the villagers, and the only Irish voice in the entirety of the play is that of Macey.

The Roman narrative complicates the sense of rootedness in place and space that is otherwise crucial to Garner's imaginary. The Roman soldiers are taken from all parts of the Empire: Magoo is from the Danube or northern frontier; Logan is perhaps from Italy; Face seems to have a lot of local knowledge, but as the captured tribal young woman says of him in the play, 'He's tribal - far from his tribe'. Macey is doubly displaced, taken from his village by Logan and the Roman soldiers, and in the film untimely ripped from the tent in which he sleeps; but even 'Macey' seems to signify the berserker persona that overtakes him in crisis, rather than the much more vulnerable visionary subject who eventually enters into some kind of emotional bond with the young woman. Garner presents the Romans as American soldiers in Vietnam, beset by guerrilla fighters in hostile territory, working with social and sacramental codes of ritual behaviour that they only partly understand. Even the local tribes are at war, with each other as much as with the Romans. The 'Cats', as they are called in the narrative, seem to be the Cornovii, who occupied much of the southern Cheshire territory; the 'Mothers' appear to be the Brigantes, who were settled more to the north of the county. There is, then, in this narrative, another triangulation, between Romans, Cats and Mothers, for control and occupation of space, but as I noted above, none of these are homogenous groupings. As the narrative progresses, with the soldiers seeking sanctuary on Mow Cop (a sacred site to the Cat tribe), the 'tribal' sensibility which underlies and is not erased by Roman 
soldier subjectivity begins to reassert itself. Garner seems to suggest that we are all 'tribal' in some sense, rooted in structures of belonging that are tied to specific spaces and places. 'Tribal' becomes a signifier for a pre-existing emotional matrix, one which is expressed in ritual and folk tale and myth. In Red Shift, the science fictional temporal structures themselves enact a 'tribal' sensibility, a way of understanding time and space that is deeply rooted in human experience.

One of the few spatial manipulations that take place in terms of presented geography in the tv adaptation of Red Shift is when Tom and Jan ride on bicycles from Crewe railway station to Mow Cop. Barthomley sits roughly between the two, and so a bicycle ride that takes in all three locations is a reasonable itinerary. However, one panning shot takes in the two riders as they pass a large radio telescope, which can only be the Lovell telescope at Jodrell Bank, some twelve miles north of Mow Cop. Garner's careful geography does not allow for such a spatial error. In Boneland (2012), the Jodrell Bank observatory plays a significant role, but is much more convincingly aligned with Alderley Edge. The Lovell telescope is, in fact, a meta-textual reference to Garner himself, and to the author's locality: in an article tiled 'The Cosmic Lighthouse' in the festschrift volume First Light (2016), Teresa Anderson (who works at the observatory) states 'Alan Garner is our almost-neighbour. His house is separated from Jodrell Bank by a couple of fields and the train line between Manchester and Crewe' (Anderson 2016: 15). Here, then, the tv adaptation of Red Shift alters its geography to mark out Cheshire as 'Garner territory': the actual, physical location of the observatory is subservient to its fictional, mythic placing. 
The 'blue-silver' of the British Rail trains that are a significant part of the mise-en-scène of the television play of Red Shift, and that is thematically crucial to both narratives, can also be found in a short television play Garner wrote that was broadcast in 1980 as part of a series of half-hour dramas entitled Leap in the Dark. Garner's play is called 'To Kill a King', which is a narrative of a blocked writer and what seems to be his muse, filmed in and around Garner's property. The opening shot of the teleplay shows a blue-silver train passing through the countryside - grey, wintry, dark - on an elevated railway embankment. As it passes out of shot, the camera rests momentarily on the Lovell telescope, before panning and refocusing on the house in the foreground, in which we can see a woman in a window. This is the 'muse'. In voice-over, we hear the voice of Harry, the writer (Anthony Bate), who awakens to find that a message is 'already coming'. The visual connection between the train, the landscape and the radio telescope, which is then further connected to an act of poetic transmission, indicates the deep vertical relation in Garner's work between place and time which is revealed through acts of transmission, in place but across time. In Red Shift, this transmission is effected by the axe-head and the male protagonists; in 'To Kill A King', this is directly a function of the act of writing itself. Harry takes dictation, but the lines heard as a female voice-over are not the ones he sets down on the page. When he shows the new work to his long-suffering agent, what is revealed is either Joycean glossolalia or a kind of invocation, a ritual spell: 'It is not a piss-one, or a tin-pot to pick with you, my lad...' it begins. Just as the Jodrell Bank telescopes 'listen' to the universe, a sky full of radio transmissions, Harry attends to the words 'coming in'. The gap between 
transmission and transcription causes Harry to have something close to a breakdown.

What we have here is then a poetic of transmission, a model of poetic creation that the contemporary British writer Tom McCarthy, in his International Necronautical Society documents, outlines as central to $20^{\text {th }}$ century poetics, from automatic writing to Rilke's Sonnets to Orpheus to Cocteau's Orphée (1950). In that film, the poet Orphée is seduced by Death through the medium of radio: another (dead) poet, Cégeste, is suborned to broadcast strange poetry for Orphée to receive and write down, and then fraudulently present as his own. McCarthy reads this relationship as follows:

What Cocteau is doing, both through Cégeste and through the CégesteOrphée setup - the transmissions between and beyond the two men - is establishing an aesthetic of repetition. Orphée, the official author of the fragments, is not their originator but rather their repeater whose composing consists first and foremost of listening. Cégeste (who we never see composing, only repeating, again and again) is also a listener, even when what he is listening to is himself. (McCarthy 2012: 166).

In Orphée, the radio becomes the (physical) medium through which transmissions in time and space are effected. The relation between communication technologies and the 'muse' or poetic creation are identified as a kind of mythic receiving of extant signals. In 'To Kill A King', this is emphasised by the increasing dominance of communications equipment within the visual compositions: a reel-to-reel tape machine; disembodied telephone messages; a typewriter that begins to print on its own; and finally television broadcasts, in which Harry is trapped inside the screen of a tv, one that appears in shot directly behind him. Is Harry a creator, a writer struggling to write and suffering mental anguish as a result? Or is he a receiver, human communications equipment that 
no longer functions properly? Harry 'escapes' this dilemma by smashing the tv screen with a rock, a stone face that he plucks then throws back, horrified, into a pond in a walk through the winter landscape. This object, like Red Shift's thunderstone, connects him directly to ritual and to place, and his 'release' is an act of symbolic and purgative violence, destroying his connection to the communications technologies of modernity and his fear of being 'switched off'.

In Red Shift, as noted above, Tom uses headphones and a cassette recorder to escape from the all-too-present proximity of his parents in the small space of the caravan. However, the presence of the shot of Jodrell Bank, the star chart that is on Tom's alcove wall, Tom and Jan's use of the constellation of Orion as a 'communications satellite' to enable them to feel each other's presence when separated, all suggest a rather more cosmological register at work. For Macey and Thomas Rowley in particular, the visions, the 'transmissions', come from a temporal and spatial elsewhere that is unidentifiable, but which challenge their own location in time and space, and threaten the unity of their subjectivity. This register, of course, bears upon the title of both novel and play, Red Shift. In one sense, the connotation is deeply material, referring in the novel to Margery's alder-dyed garment, a 'red shift', that is momentarily glimpsed in the tv play. However, it also refers to the notion of an expanding universe, in which the spectrum of light emitted by stars is shifted towards the red end of the spectrum as they move away from the observer. Stephen Hawking, in A Brief History of Time (1988), explains it thus:

Imagine a source of light at a constant distance from us, such as a star, emitting waves of light at a constant frequency. Obviously the frequency of the waves we receive will be the same as the frequency at which they are emitted. [...] [I]f the source is moving away from us, the frequency of the waves we receive will be lower. In the case of light, therefore, this 
means that stars moving away from us will have their spectra shifted toward the red end of the spectrum (red-shifted) and those moving toward us will have their spectra blue-shifted. This relationship between frequency and speed, which is called the Doppler effect, is an everyday experience. Listen to a car passing on the road: as the car is approaching, its engine sounds at a higher pitch (corresponding to a higher frequency of sound waves), and when it passes and goes away, it sounds at a lower pitch. The behaviour of light or radio waves is similar. (Hawking 1988: 42-3).

As we noted above, both texts of Red Shift begin by the M6 motorway, and the television film uses the Doppler effect of cars passing as a thematic connection. Garner, I would suggest, uses the 'red shift' as a metaphor more generally for emotional (and in the case of Tom and Jan, physical) distance. Towards the end, Tom cries out in anguish: 'I need a red shift. I need to see. The further they go, the faster they leave. The stars are emptying.' Tom, as I have noted above, cannot see, unlike Macey or Thomas; in his narrative, there is no resolution or restitution through an emotional bond with the female loved-one, as is afforded the other two characters. He remains blocked and isolated.

Although I have concentrated here on the male protagonists, their connection in space and time, and their relation to the history and topography of Cheshire, I should pause to emphasise the crucial mythic role played by each of the three main female characters: the captured and unnamed Cat girl (Veronica Quilligan), who eventually poisons the soldiers with ergotic grain, as they have desecrated Mow Cop; Margery Rowley, whose love for Thomas causes them to be saved from death; and Jan, whose sexual experience causes such emotional disturbance for both Tom and his priggish mother. These women are rooted in the material in a way that the men are not: Margery's red shift, as noted, is a dyed undergarment. Their use of language is earthy, profane even: Margery tells 
Thomas Fowler to 'bugger off' and Jan tells Tom's mother to 'piss off', and if they cannot see as the men do (or need to do), then their connection to life (and to their own bodies) is much less troubled. Their language is utile, not poetic. They enable the survival of the men (except in Tom's case, who cannot accept Jan's experience), and by doing so, create the temporal continuum which transmits the axe-head from Macey to Thomas to Tom. It is significant that Tom's greatest betrayal is selling the object to the museum, and it is equally significant that the tv play ends with a shot of the axe in a display case: although he declaims that it is not a possession, he is the one who sells the object and misunderstands its value to himself and to Jan. As Carolyn Gillies suggests, the 'theme of material possession is very strong in this book and is in fact the link holding the separate strands together' (Gillies 1975: 115), but it is not possession in terms of the political domination of territory (as in the Civil War or Roman narratives): in a sense the object possesses the person in ensuring trans-temporal connection. Jan understands, emotionally rather than intellectually, the importance of this transmission, where Tom cannot.

The tv play ends with Jan leaving Crewe station for London, and then Tom, walking to the stairway, looking down a darkened passage; the camera moves in, and there is a spatial transition to the museum, with the axe-head in its case. While ambiguous, the play strongly suggests that Tom and Jan's parting is terminal, the breach irreparable. The novel ends differently. After they say 'see you' (rather than 'hallo'), the last line of the novel proper is 'It doesn't matter. Not really now not any more' (Garner 2002: 189). But on the following two pages a coded letter is printed, one that invites the reader to decode it using the key that Tom and Jan use themselves. The message reads: 
I love you. If you can read this you must care. Help me. I'm writing before we meet, because I know it'll be the last. I'll put the letter in your bag, so you'll find it on the train afterwards. I'm sorry. It's my fault. Everything's clear, but it's too late. I'll be at Crewe next time. If you don't come I'll go to Barthomley. I love you. The smell of your hair will be in my face. (Mapson: 2000)

This is a final transmission, one, in effect, to the void. Tom knows that Jan will not return, and so it is a farewell, an apology, but also a suggestion that a blockage has been undone: 'everything's clear', vision has been achieved, albeit too late for them. The novel asks us to enact a moment of decoding or unlocking as its final gesture, but if we turn again to Tom McCarthy, even that gesture becomes ambiguous and problematic. 'All code is burial,' he writes; 'To move toward it (as Orphée does) is to move towards death, and to operate within it (as Cégeste does) is to be already dead' (McCarthy 2012: 173). This coded transmission is also buried, in Jan's handbag, as the axe-head had been in the ground; but is Tom moving towards code or away, towards others or further into distance? Is his movement a blue-shift or a red-shift? One must suspect that even clarity, for Tom, does not equate with connection.

Cheshire was, and remains, Garner's territory. In his texts, myth and history themselves occupy an undefined boundary, and so Cheshire, a boundary zone between the English North and South, between England and Wales, is fertile ground for explorations of the continuity of space in time, and time in space. Just as Cheshire (and Red Shift) are traversed by the networks of modernity's communications and transport systems, Garner's novels cross time and space, and cross borders and boundaries. Like Cheshire's railways and motorways, and like the Jodrell Bank radio telescope, Garner's texts are of the county but always orient themselves outwards and elsewhere. 


\section{Bibliography}

Anderson, Teresa (2016). 'The Cosmic Lighthouse: Alan Garner and Jodrell Bank', in Erica Wagner (ed.), First Light: a celebration of Alan Garner (London: Unbound), pp.15-19.

Crosby, Alan (1996). A History of Cheshire (Chichester: Phillimore).

Garner, Alan (1992) [1960]. The Weirdstone of Brisingamen (London:

HarperCollins).

Garner, Alan (1992b) [1967]. The Owl Service (London: HarperCollins).

Garner, Alan (1997a). 'Inner Time', in The Voice That Thunders (London: Harvill), pp.106-125.

Garner, Alan (1997b). 'The Edge of the Ceiling', in The Voice That Thunders (London: Harvill), pp.3-18.

Garner, Alan (2002) [1973]. Red Shift (London: HarperCollins).

Garner, Alan (2002b) [1962]. The Moon of Gomrath (London: CollinsVoyager).

Garner, Alan (2004) [2003]. Thursbitch (London: Vintage).

Garner, Alan (2008) [1965]. Elidor (London: HarperCollins).

Garner, Alan (2012) Boneland (London: Fourth Estate).

Gilllies, Carolyn (1975). 'Possession and structure in the novels of Alan Garner', Children's Literature in Education, September, 6:3, pp.107-117.

Hawking, Stephen (1988). A Brief History of Time: From the Big Bang to Black Holes (London: Bantam).

Mapson, R. (2000) 'The Red Shift Code - Solution', The Unofficial Alan Garner website. http://alangarner.atspace.org/solution.html, accessed 12 April 2016. 
McCarthy, Tom (2012). 'Calling All Agents', The Mattering of Matter: Documents from the Archive of the International Necronautical Society (Berlin: Sternberg), pp.163-216.

Morley, Paul (2014). The North (and almost everything in it) (London:

Bloomsbury).

Philip, Neil (1981). A Fine Anger: A critical introduction to the work of Alan Garner (London: Collins).

\section{Filmography}

Red Shift (1978). Dir. John Mackenzie. BBC Television, tx. 17 January 1978. BFI dvd.

The Owl Service (1969). Dir. Peter Plummer. Granada Television, tx. 28 December 1969 - February 1970. Network dvd.

To Kill A King (1980). BBC Television, tx. 12 September 1980.

https://www.youtube.com/watch?v=kZiu8uEcPTY, accessed 10 October 2015. 